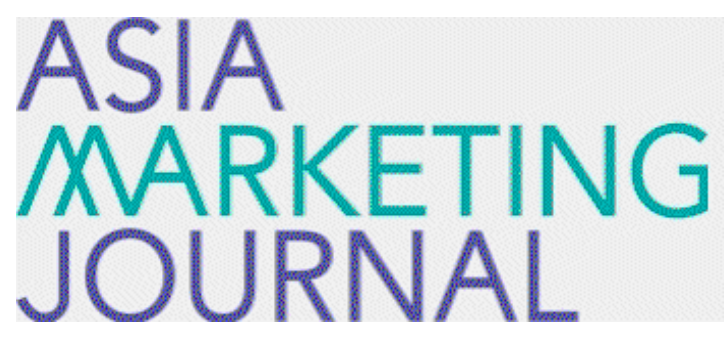

ASIA MARKETING JOURNAL

Volume 23 | Issue 2

Article 4

8-1-2021

\title{
Retail Employees' Ethical Value and Climate on Multidimensional Job Satisfaction: A Comparative Study with B2B Employees
}

Hyowon Hyun

Yonsei University, hhwony326@gmail.com

Jungkun Park

Hanyang University, viroid2007@gmail.com

Jihwan Yum

Hanyang Cyber University, jhyum@hycu.ac.kr

Sangwoo Lee

Hanyang University, polo0629@naver.com

Follow this and additional works at: https://amj.kma.re.kr/journal

Part of the Marketing Commons

\section{Recommended Citation}

Hyun, Hyowon; Park, Jungkun; Yum, Jihwan; and Lee, Sangwoo (2021) "Retail Employees' Ethical Value and Climate on Multidimensional Job Satisfaction: A Comparative Study with B2B Employees," Asia Marketing Journal: Vol. 23 : Iss. 2 , Article 4.

Available at: https://doi.org/10.53728/2765-6500.1181

This Article is brought to you for free and open access by Asia Marketing Journal. It has been accepted for inclusion in Asia Marketing Journal by an authorized editor of Asia Marketing Journal. 


\title{
Retail Employees' Ethical Value and Climate on Multidimensional Job Satisfaction: A Comparative Study with B2B Employees*
}

\author{
Hyowon Hyun** \\ Jungkun Park P** $^{* *}$ \\ Jihwan Yum**** \\ Sangwoo Lee L***** $^{*}$
}

\begin{abstract}
In the retail industry, managing companies' ethical environments is critical because it is associated with employee satisfaction and performance. Despite the increasing demand to understand the role of salespersons' ethical climate and value on behavior, only a few studies have focused on this connection. Furthermore, the relative impact of ethical issues (e.g., ethical value and ethical climate) on multidimensional job satisfaction in B2B and B2C sectors remains unexplored. Thus, this study 1) explores the impact of ethical issues (e.g., ethical value and ethical climate) on multi-dimensions of job satisfaction (e.g., satisfaction with management, supervisor, co-workers, and customers) and 2) compares the relationship between job satisfaction across and ethical climate $\mathrm{B} 2 \mathrm{~B}$ and $\mathrm{B} 2 \mathrm{C}$ settings. By using an online survey in the U.S., a total of 492 questionnaires were collected from salespersons in B2B and B2C settings. Structural equation modelling shows that the ethical value influences job satisfaction more significantly among salespeople in the B2B setting, whereas the ethical climate has a greater impact in the B2C setting. Thus, given the importance of sustainability, this study provides practical implications on how to understand employee behavior by adjusting the ethical environment to increase employee satisfaction.
\end{abstract}

Keywords: business-to-business, business-to-consumer, ethical climate, salespersons' job satisfaction

\footnotetext{
* This work was supported by the research fund of Hanyang University (HY-2021)

** Ph.D. Yonsei University (hhwony326@gmail.com)

*** Ph.D. Hanyang University (viroid2007@gmail.com), Corresponding Author

**** Ph.D. Hanyang Cyber University (jhyum@hycu.ac.kr)

***** Graduate Associate Hanyang University (polo0629@naver.com)
} 


\section{Introduction}

The ethical activities of organizations are an important factor for various stakeholders composing the organization (i.e., business owners, shareholders, the management, employees, customers, labor unions, corporations, etc.) in evaluating the organization (Park et al., 2010).

Especially, in the service industry, organizational climate is a dominant factor in employee performance and commitment (Jafri, Dem, and Choden 2016 62; Parsons and Broadbridge 2006: Westerman and Simmons 2007; Yu et al. 2018). Employees' perception of organizational climate can directly or indirectly influence employees' behavior (Teng and Barrows 2009; Wang 2012; Zhang et al. 2011). Ethical climate is defined as a shared perceptions held by its employees regarding the organization's policies, norms, business practices, and managerial procedures (Martin and Cullen 2006). The ethical climate is important because an organization's ethical climate dictates its ethical values and job satisfaction is expected to be influenced by the valence of organizational climate (Ahmad et al. 2010; Ekvall 1996). For instance, Wang and Hsieh (2012) suggested that organizational ethic climate is related to desired organizational outcomes, such as job satisfaction. Also, a significant impact of ethical climate and value on organizational commitment (Sims and Kroeck 1994), role conflict (Schwepker, Ferrell and
Ingram 1997), job satisfaction (Vitell and Davis 1990), turnover intention (Sims and Kroeck 1994), and job performance (Weeks and Nantel 1992) were found.

In the global arena, there is strong evidence of organizational climate manifested in businessto-business (B2B) and business-to-customer (B2C) settings (Deshpandé and Farley 2004; Ekvall 1996; Jones, Busch, and Dacin 2003; Luthans et al. 2008; Patterson, Warr, and West 2004). The nature of service industries varies across B2B and B2C sectors (Hoejmose, Brammer, and Millington 2012; Swani, Brown, and Milne 2014). For instance, organizations in B2B markets often show little effort to create friendly and trustful organizational climates. In contrast, in the $\mathrm{B} 2 \mathrm{C}$ setting, companies are more likely to cultivate positive organizational climate, because it is an important antecedent for creating customer satisfaction. In line with this, there is increasing pressure for marketing and retail practitioners in B2B settings to improve their organizational climate. These practitioners must respond both to external pressure and to the general belief that organizational climate can improve an organization's performance providing a competitive advantage in business. According to Yẽn (2019), positive organization climate helps employees help improve their productivity and quality. Conversely, dissatisfied employees have a negative impact by leaving the organization or by making less effort to participate (Whysall, Foster, and Harris; 2009). 
Although ethical issues (e.g., ethical value and ethical climate) are related to the different types of job satisfaction (El'Fred and Koh, 2001; Pettijohn, Pettijohn, and Taylor 2008; Wong and Li 2015), previous studies mainly have focused on the concept of ethical issues in B2C sectors (Pettijohn, Pettijohn, and Taylor 2008; Schwepker Jr and Hartline 2005). Furthermore, despite the complexity of service employees' work environments little is known about the influence of ethical issues on multidimensional job satisfaction (promotions, pay, co-workers, supervisors, and customer satisfaction) (Deshpande 1996; Mayer et al. 2009). In order to fill these gaps between industry and academia, the authors aim to 1) understand the role of two types of ethical issues including value and climate, 2) examine the link between ethical issues and employees' multidimensional job satisfaction, and 3) compare the effect of ethical environments on job satisfaction between B2B employees and B2C employees.

Thus, this study contributes to the existing service literature in three ways. First, it provides an integrated insight on employees' behavior study by considering the role of both ethical climate and value. This extended framework provides a useful perspective to understand the impact of an ethical environment on employee satisfaction. Second, this study focused on the importance of employees' multidimensional satisfaction in the service environment. Currently, there is limited work investigating the link between ethical conditions and employees' evaluation of complicated work environments; this study provides a comprehensive understanding of this issue. Lastly, by examining both B2B and B2C work environments, this study extends the generalizability of the results compared to previous studies that focused on a single industry setting.

\section{Review of literature}

\subsection{Ethical values and climates}

Organization value affects employees' behaviour (Kwon, Beatty and Lueg 2000). Organizational value is important because it is an indicator of service employees' job satisfaction, engagement, and organizational commitment, and intention to leave an organization (Schwepker Jr 2001; Verplanken 2004). Among various perceived values, organization ethical values have been referred to as the foccal dimension of an organization's culture and have been treated as powerful influences differentiating one company from another (Alchian and Demsetz 1972). In line with this, an organization's ethical value is conceptualized as a subset of the organization's cultural value (Hunt et al. 1989). Ethical value is defined as the summation of the ones values of managers and both the formal or informal 
ethics policies of the organization (Hunt, Wood, and Chonko 1989).

Ethical climate is considered as a reflection of organizational policies, procedures, and practices with moral consequences (Cullen, Parboteeah, and Victor 2003). Ethical climate contains cues that guide employees' behavior (Cullen, Parboteeah, and Victor 2003). Thus, ethical climate is related to the employees' perceptions about the organization's procedures, norms, current practices, and values with ethical cues about ethical behaviors (Babin, Boles, and Robin 2000). Ethical climate relates to the organization's atmosphere allowing ethical values to be seen as a deeper and broader construct, including factors enhancing ethical behavior (Heugen et al. 2006; Kaptein 2011; Treviño and Weaver 2003). Recently, the ethical value has been combined with that of employee wellbeing regard to the ethical strain, burnout, and work engagement (Huhtala et al. 2011; Huhtala et al. 2013). When there is good fit between ethical value and ethical climate in the organization, employees' work experiences is more positive and it is likely to enhance goal attainment and attachment to work (Lau et al. 2017; Sims and Keon 1997; Valentine and Barnett 2003). In the retail context, Lau et al. (2017) found the impact of employees perceived ethical work climate on their affective commitment and service performance.

According to the cognitive dissonance theory (Festinger, 1957), individuals desire to minimize dissonance in their environment because continued dissonance indicates distress and dissatisfaction (Viswesvaran, Deshpande, and Joseph (1998). Thus, employees look for consistency between ethical values of their own and organizational ethical climate (Schwepker, 1999). At the employee level, ethical values influence the moral reasoning of individuals, which influences the overall value system of the individuals.

When there is a good fit between ethical values and ethical climate, employees' work experiences are more positive, and it is likely to enhance goal attainment and attachment to work (Lau et al. 2017; Sims and Keon 1997; Valentine and Barnett 2003). In the retailing context, Lau et al. (2017) found that employees' perceived ethical work climate influences their affective commitment and service performance. Generally, the better the ethical fit between the employee and the organization, the higher the levels of commitment and job satisfaction of the employee, and the lower the turnover intent (Ambrose, Arnaud, and Schminke, 2008). For instance, in the foodservice industry, Jung, Namkung, and Yoon (2010) found an interrelationship between employees' perceptions of business ethics and the individual-organization fit, while a high level of fit influences the turnover intention. A positive link between ethical culture and job satisfaction with its impact on organizational commitment was also supported from the exploratory study of managers in Singapore (Chye Koh and Boo, 2004). 
Most of the research examined normal relationships (e.g., fit), not causal relationships, between the ethical values of employees and the organizational ethical climate. For instance and Chatman (1991) explored the impact of congruence between attributes of individuals and attributes of job and organization. Although the fit between employee' ethical values and the organization's ethical climate affect their behavior, it is unknown whether the individual level of ethical perception influences the organization level. Thus, in this study, the causal effect of the ethical values of employees on an organization's ethical climate is assumed. The following hypothesis is advanced.

$H_{1}$ : Employee's perceived ethical value of organization positively influences the ethical climate in the work environment.

\subsection{Multi-dimensions of job satisfaction}

Organization's ethical issues (e.g., ethical value, ethical climate) on corporate environment should impact employees' job satisfaction (Schwepker Jr 2001; Verplanken 2004). Organizational culture contributes to the significant impacts on organizational commitment and job satisfaction (Malik et al. 2011; Yousef 2001) and turnover intention (Booth and Hamer 2007). Organization's ethical issues (e.g., ethical value, ethical climate) and their effect on service employees' job satisfaction have been important topics for both academics and practitioners for a long time (Coelho et al. 2010; Yeşiltaş and Tuna 2018). The academic research has a long history of investigating salesperson multi-faceted job satisfaction (Chung, Rutherford, and Park 2012; Hartmann, Rutherford, and Park 2017). Multifaceted job satisfaction analysis provides a depper understanding of job satisfaction than do a single instruments by accounting for satisfaction with multiple sub variables (Rutherford, Boles, and Ambrose 2019). For instance, Hartmann, Rutherford, and Park. (2017) explored the sequencing of salesperson multi-faceted job satisfaction, and the results indicated that for B2C salespeople, satisfaction with supervisor has a great effect on satisfaction with co-workers. Also, their findings provided that satisfaction of customers is an important factor in the B2B context (Hartmann, Rutherford, and Park 2017). Lee and Gao (2005) found that higher satisfaction with salaries and supervisors lowered employees' tendency to leave the organization. Thus, it is important to understand multidimensional job satisfaction between B2B employees (i.e., suppliers) and B2C employees' settings.

\subsection{Antecedents of sales persons' job satisfaction}

Based on the study of Anaza et al. (2015), which examined the job satisfaction of sales employees from multiple perspectives (i.e., 
governance, social, egocentric, instrumental), this study verified the job satisfaction of B2B and $\mathrm{B} 2 \mathrm{C}$ organizations according to various job positions (i.e., satisfaction with management, co-workers, supervisor, and customer).

First, satisfaction with management can be broadly grouped as governance satisfaction factors and evaluates the extent to which an organization has knowledge and management competency related to tasks. Second, the satisfaction of co-workers, supervisors, and customers are dimensions included in social satisfaction factors and evaluate the relationship with people interacting in the process of performing tasks within the organization. Because organizational ethical environment acts as an important influencing factor on various work-based conditions (Anaza et al, 2015). Particularly, in the service industry, there is a positive link between ethical culture and job satisfaction and its impact on organizational commitment (Chye Koh and Boo 2004). For instance, the organization's ethical environment was found to influence managers' job satisfaction positively in Singapore (Koh and El'Fred 2001). Also, among front-line service employees, their positive perceptions of co-worker association and supervisory support significantly influence their own job performance and job satisfaction (Babin and Boles 1996). The effect of employees' ethical climate satisfaction on their satisfaction of their supervisor and their job was also suggested in the pharmaceutical industry
(Mulki, Jaramillo, and Locander 2009). Also, a company's ethical reputation led customer satisfaction and loyalty based on customer trust (Chiou, Droge, and Hanvanich 2002).

Job satisfaction is an attitude that is associated with a company's ethical environements, especially where there is employee's belief that the organization and its upper-level management promote ethical conduct (Jaramillo, Mulki, and Solomon 2006; Prottas 2013). Ethical leadership can reduce anxiety and address uncertainty in ethical situations by giving attention, openness, trust, and honesty (Aryati et al. 2018). Ethical environments embedded in the organization can influence employees' perception of ethical value and climate. More specifically, employees' attitudes and behaviors are more positive in an ethical environment, as shown through enhancing goal attainment, attachment to work, and person - company value fit (Sims and Kroeck 1994; Sims and Keon 1997). Supervisors can make the work environment better, and this environment plays a positive role in employee satisfaction (Ashraf 2019). According to Schwepker (2019), employees are committed to their work when the ethical value of the organization is consistent with their value, and in order to create customer value, ethical sales behavior of the operator is paramount, which helps them maintain a long-term relationship by increasing customer satisfaction. Thus, in the service setting, employees' satisfaction with the job consists of satisfaction with management, 
co-workers, supervisors, and customers. Thus, the following hypotheses were formulated.

$\mathrm{H}_{2}$ : Organization's ethical value positively influences job satisfaction with management.

$\mathrm{H}_{3}$ : Organization's ethical value positively influences job satisfaction with co-workers.

$H_{4}$ : Organization's ethical value positively influences job satisfaction with supervisors.

$H_{5}$ : Organization's ethical value positively influences job satisfaction with customers.

An organization's environment influences employees' multi-dimensional job satisfaction. For instance, the ethical environment of the organization is a strong predictor of managers' job satisfaction (Viswesvaran, Deshpande, and Joseph 1998). In the same vein, researchers found a positive impact of ethical climate on job satisfaction for management, co-workers, supervisors, and co-workers (Joseph and Deshpande 1997). Mulki, Jaramillo, and Locander (2009) also found the effect of employees' perception of ethical climate on their satisfaction with their supervisor and job. Ethical environments affect the ethical behavior of co-workers, and these behaviors have positive effects on job satisfaction, such as creating beneficial behaviors (e.g., cooperation, helping) for the group and reducing the rate of departure (Ambrose, Rice, and Mayer 2019). Ethical climate is deeply associated with customer orientation that may enhance the salesperson's ability to develop long-term relationships with their customers (Schwepker Jr and Good 2004). The long-term relationship between a customer and a salesperson is derived from customer satisfaction. However, the negative influence of ethical climate types (instrumental) on overall job satisfaction and satisfaction with co-workers, promotions, and supervisors was supported in non-profit organization (Deshpande 1996). Because of this inconsistency in terms of the impact of the ethical environment on employees' job satisfaction, the current study examined the relationship among ethical value, ethical climate, and multi-dimension of job satisfaction.

$H_{6}$ : Organization's ethical climate positively influences job satisfaction with management.

$\mathrm{H}_{7}$ : Organization's ethical climate positively influences job satisfaction with co-workers.

$H_{8}$ : Organization's ethical climate positively influences job satisfaction with supervisors.

$H_{9}$ : Organization's ethical climate positively influences job satisfaction with customers.

\subsection{Ethical issues in service environments across b2b and b2c contexts}

In the service industry, a salesperson's job satisfaction has been regarded as one of the crucial factors in both B2B and B2C environments (Abbott 2003). For instance, salespeople are the supreme drivers of business; however, low organizational commitment and high turnover 
rate among salespeople in both $\mathrm{B} 2 \mathrm{~B}$ and $\mathrm{B} 2 \mathrm{C}$ settings have been acknowledged as threatening for the entire market (Hurst and Good 2009). Employee perceptions of job satisfaction can certainly explain employee workplace attitudes and their working behavior. Riggle, Edmondson, and Hansen (2009) stated that the work environment is the key consideration for employees' job satisfaction. Since B2B and B2C are different business environments, each of them could have differences in the strengths of relationships among the determinants of job satisfactions (Brown and Lam 2008).

The comparison study of satisfaction in both the $\mathrm{B} 2 \mathrm{~B}$ and $\mathrm{B} 2 \mathrm{C}$ context has been conducted by previous research, which focused on salespeople and consumer perspective (Mencarelli and Riviere 2014). For instance, according to Hartmann, Rutherford, and Park (2017), B2C salespeople have less protracted selling cycles and shorter and less rational decision-making processes compared to B2B salespeople. However, B2B salespeople include many decision makers and they always play a role as coordinator of the internal and external sources to present customized solutions. This means that B2B salespeople involve closely and comparably longer relationships with a smaller number of customers than do in B2C. (Dixon and Tanner Jr 2012; Plouffe, Sridharan, and Barclay 2010). Thus, based on the previous studies, the following hypothesis was proposed.

$$
\begin{aligned}
H_{10}: & B 2 b \text { employees' job satisfaction is } \\
& \text { comparably strongly influenced by ethical } \\
& \text { environments than } B 2 C \text { employees. }
\end{aligned}
$$

The proposed framework (Figure 1) shows the impact of ethical value and climate on multidimensional job satisfaction.

〈Figure 1〉 Conceptual Model of Ethical Value and Multiple Job Satisfaction

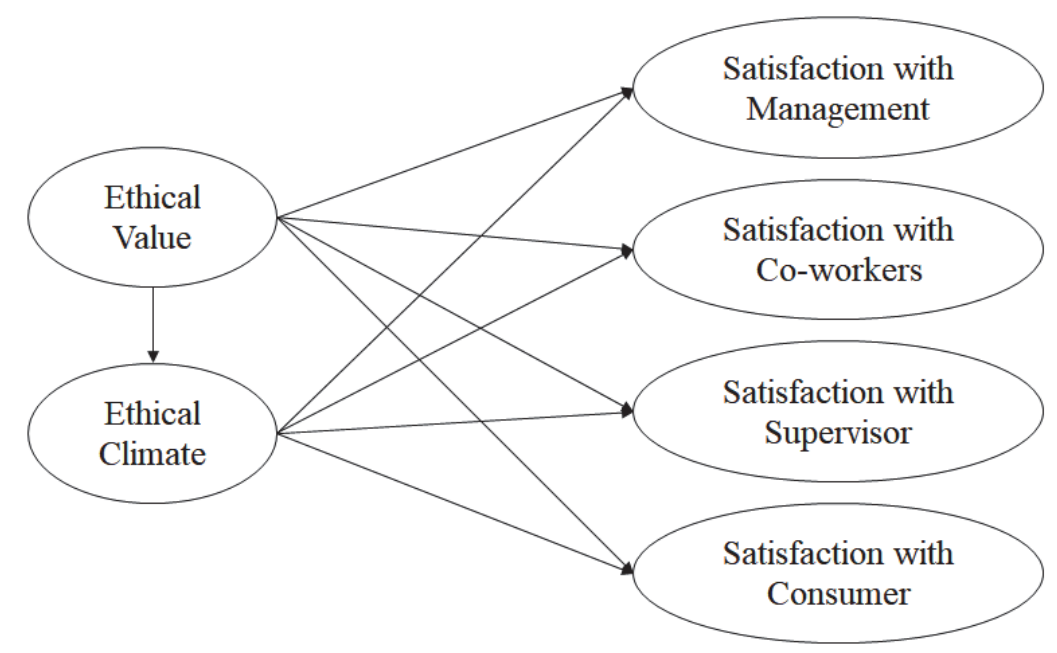




\section{Methodology}

\subsection{Data collection}

The population of this study is salespeople in B2B (i.e., suppliers) and B2C (retailing) settings. To obtain a sample from the United States' retail and B2B employees, data was collected using an online panel with a screening question asking about their customers. A total of 492 questionnaires were collected for both groups, with respondents as working in sales within B2B ( $n=263)$ or B2C ( $n=229)$. Table 1 indicates a characteristic of the $\mathrm{B} 2 \mathrm{~B}$ and $\mathrm{B} 2 \mathrm{C}$ e,ployees. Four types of information were obtained from each participant: individual level of ethical value, organizational ethical climate, individual demographics, and job satisfaction (satisfaction with management, co-workers, supervisor, and customer). The individual demographic instrument was asked last on all surveys, asking basic demographic information including age, gender, and job position. Scale items in this study are measured on seven-point Likert-type scales. For job position, in the B2B group, 59.4\% were in regular employee $59.4 \%$ and manager were in $14.8 \%$. Also, the B2C group, regular employee was the most common with $71.1 \%$ (Table 2).

The ethical climate of the organization was tested utilizing the ethical climate questionnaire developed by Victor and Cullen (1987). Job satisfaction was measured with a modified version of Churchill, Ford, and Walker (1974)'s study along with Comer, Machleit, and Lagace (1989)'s, a scale that assesses employees' satisfaction with their management, co-workers, supervisor, and customer (Table 3).

〈Table 1〉 Respondents' socio-demographic characteristics.

\begin{tabular}{cccc}
\hline Variable & Group & Frequency & Percent \\
\hline \multirow{3}{*}{ Age } & $\langle 30$ years of age & 59 & 12.1 \\
& $31-40$ & 88 & 18.0 \\
& $41-50$ & 120 & 24.5 \\
& $51-60$ & 139 & 28.4 \\
& $>$ years of age & 83 & 17.0 \\
Gender & Total & 489 & 100.0 \\
& Male & 207 & 43.1 \\
& Female & 273 & 56.9 \\
\multirow{3}{*}{ Position } & Total & 480 & 100.0 \\
& B2C & 263 & 53.5 \\
& B2B & 229 & 46.5 \\
\hline
\end{tabular}


〈Table 2〉 Respondents' job position

\begin{tabular}{|c|c|c|c|}
\hline Industrial & Job position & Frequency & Percent \\
\hline \multirow{7}{*}{$\mathrm{B} 2 \mathrm{~B}$} & Regular employee & 136 & 59.4 \\
\hline & Assistant manager & 3 & 1.3 \\
\hline & Manager & 34 & 14.8 \\
\hline & Director & 2 & 0.9 \\
\hline & Executives & 35 & 15.3 \\
\hline & $\mathrm{CEO}$ & 19 & 8.3 \\
\hline & Total & 229 & 100.0 \\
\hline \multirow{7}{*}{$\mathrm{B} 2 \mathrm{C}$} & Regular employee & 187 & 71.1 \\
\hline & Assistant manager & 0 & 0.0 \\
\hline & Manager & 34 & 12.9 \\
\hline & Director & 7 & 2.7 \\
\hline & Executives & 16 & 6.1 \\
\hline & $\mathrm{CEO}$ & 19 & 7.2 \\
\hline & Total & 263 & 100.0 \\
\hline
\end{tabular}

〈Table 3〉 Definition and measurements of variables.

\begin{tabular}{|c|c|}
\hline Construct & Measurement items \\
\hline $\begin{array}{l}\text { Ethics } \\
\text { Values }\end{array}$ & $\begin{array}{l}\text { 1. If a manager in my company is discovered to have engaged in unethical behavior } \\
\text { that results primarily in personal gain (rather than corporate gain), he or she will } \\
\text { be promptly reprimanded. } \\
\text { 2. If a manager in my company is discovered to have engaged in unethical behavior } \\
\text { that results primarily in corporate gain (rather than personal gain), he or she will } \\
\text { be promptly reprimanded. }\end{array}$ \\
\hline $\begin{array}{l}\text { Ethics } \\
\text { Climate }\end{array}$ & $\begin{array}{l}\text { 1. My company has policies with regard to ethical behavior. } \\
\text { 2. My company strictly enforces policies regarding ethical behavior. } \\
\text { 3. Top management in my company has let it be known, in no uncertain terms, that } \\
\text { unethical behavior will not be tolerated }\end{array}$ \\
\hline $\begin{array}{l}\text { Satisfaction on } \\
\text { Management }\end{array}$ & $\begin{array}{l}\text { 1. Management is progressive. } \\
\text { 2. Top management really knows its job. } \\
\text { 3. This company operates efficiently and smoothly. } \\
\text { 4. Sales persons in the company receive good support from the home office. }\end{array}$ \\
\hline $\begin{array}{l}\text { Satisfaction on } \\
\text { Co-Workers }\end{array}$ & $\begin{array}{l}\text { 1. My fellow workers are pleasant. } \\
\text { 2. The people I work with are very friendly. } \\
\text { 3. The people I work with help each other out when someone falls behind or gets in } \\
\text { a tight spot. }\end{array}$ \\
\hline $\begin{array}{l}\text { Satisfaction on } \\
\text { Supervisor }\end{array}$ & $\begin{array}{l}\text { 1. My supervisor really tries to get our ideas about things. } \\
\text { 2. My supervisor has always been fair in dealings with me. } \\
\text { 3. My supervisor gives us credit and praise for work well done. } \\
\text { 4. My supervisor lives up to his/her promises. }\end{array}$ \\
\hline $\begin{array}{l}\text { Satisfaction on } \\
\text { Customers }\end{array}$ & $\begin{array}{l}\text { 1. My customers live up to their promises. } \\
\text { 2. My customers are trustworthy. } \\
\text { 3. My customers are loyal. } \\
\text { 4. My customers are understanding. }\end{array}$ \\
\hline
\end{tabular}




\subsection{Common Method Variance}

To rule out common data collection bias, this study performed factor analysis on the latent variables in the proposed model (Thurstone, 1931). For the data, the scores of all dimensions were more than 0.5. This result implies that these dimensions fully reflect that factor (see Table 4). The results of factor analysis show that some items were dropped for weak loadings and items were clearly loaded on four constructs (8.482, 2.721, 1.918, 1.623, 1.047, .872, .474, .382, .348, .323, .252, .226, .201, .199, .181, .171, $.165, .150, .142, .121)$.

\subsection{Single-group measurement model}

All standardized factor loadings are significant and greater than 0.50 (see Table 3.). The results provides evidence of convergent validity. Cronbach alpha reliabilities, composite reliabilities, and average variance extracted estimates(AVE) exceed recommended numbers providing further evidence of convergent validity (see Table 5).

The AVE estimate for all constructs are greater than the corresponding squared correlation estimates (Fornell and Larcker 1981), while the AVE estimate for each facet is greater than both maximums shared squared variance

$\langle$ Table 4〉 Common Method Variance tests.

\begin{tabular}{c|c|c|c|c|c|c}
\hline \multirow{2}{*}{ Factor } & \multicolumn{5}{|c|}{ Initial Eigenvalues } & \multicolumn{3}{c}{ Extraction Sums of Squared Loadings } \\
\hline & Total & \% of Variance & Cumulative \% & Total & \% of Variance & Cumulative \% \\
\hline 1 & 8.220 & 41.101 & 41.101 & 7.660 & 38.301 & 38.301 \\
\hline 2 & 3.036 & 15.181 & 56.282 & & & \\
\hline 3 & 2.031 & 10.153 & 66.435 & & & \\
\hline 4 & 1.618 & 8.088 & 74.523 & & & \\
\hline 5 & 1.050 & 5.252 & 79.775 & & & \\
\hline 6 & .947 & 4.737 & 84.512 & & & \\
\hline 7 & .526 & 2.631 & 87.143 & & & \\
\hline 8 & .390 & 1.950 & 89.093 & & & \\
\hline 9 & .349 & 1.747 & 90.840 & & & \\
\hline 10 & .329 & 1.644 & 92.484 & & & \\
\hline 11 & .257 & 1.283 & 93.767 & & & \\
\hline 12 & .190 & .951 & 94.718 & & & \\
\hline 13 & .183 & .915 & 95.634 & & & \\
\hline 14 & .175 & .873 & 96.506 & & & \\
\hline 15 & .156 & .778 & 97.284 & & & \\
\hline 16 & .136 & .681 & 97.965 & & & \\
\hline 17 & .128 & .641 & 98.605 & & & \\
\hline 18 & .114 & .572 & 99.178 & & & \\
\hline 19 & .087 & .434 & 99.611 & & & \\
\hline 20 & .078 & .389 & 100.000 & & & \\
\hline Ext & & & & & \\
\hline
\end{tabular}

Extraction Method: Principal Axis Factoring. 
$\langle$ Table 5〉 Reliability and validity tests

\begin{tabular}{|c|c|c|c|c|c|c|c|}
\hline Construct & Indicator & Loading & $t$-value & $\mathrm{SMC}$ & Cronbach- $\alpha$ & AVE & C.R \\
\hline \multirow{2}{*}{ Ethics Values } & EV 1 & 0.87 & 24.57 & 0.78 & \multirow{2}{*}{0.92} & \multirow{2}{*}{0.86} & \multirow{2}{*}{0.77} \\
\hline & EV 2 & 1.00 & - & 0.94 & & & \\
\hline \multirow{3}{*}{ Ethics Climate } & EC 1 & 1.00 & - & 0.67 & \multirow{3}{*}{0.90} & \multirow{3}{*}{0.76} & \multirow{3}{*}{0.75} \\
\hline & EC 2 & 1.15 & 23.48 & 0.80 & & & \\
\hline & EC 3 & 1.12 & 23.42 & 0.80 & & & \\
\hline \multirow{4}{*}{$\begin{array}{l}\text { Satisfaction on } \\
\text { Management }\end{array}$} & SM 1 & 1.00 & - & 0.52 & \multirow{4}{*}{0.89} & \multirow{4}{*}{0.68} & \multirow{4}{*}{0.77} \\
\hline & SM 2 & 1.30 & 17.94 & 0.70 & & & \\
\hline & SM 3 & 1.41 & 19.43 & 0.84 & & & \\
\hline & SM 4 & 1.31 & 17.68 & 0.68 & & & \\
\hline \multirow{3}{*}{$\begin{array}{l}\text { Satisfaction on } \\
\text { Co-Workers }\end{array}$} & SW 1 & 1.00 & - & 0.82 & \multirow{3}{*}{0.88} & \multirow{3}{*}{0.74} & \multirow{3}{*}{0.82} \\
\hline & SW 2 & 1.06 & 28.20 & 0.85 & & & \\
\hline & SW 3 & 1.04 & 20.71 & 0.57 & & & \\
\hline \multirow{4}{*}{$\begin{array}{l}\text { Satisfaction on } \\
\text { Supervisor }\end{array}$} & SS 1 & 1.00 & - & 0.74 & \multirow{4}{*}{0.95} & \multirow{4}{*}{0.82} & \multirow{4}{*}{0.86} \\
\hline & SS 2 & 1.01 & 29.22 & 0.84 & & & \\
\hline & SS 3 & 1.03 & 29.34 & 0.84 & & & \\
\hline & SS 4 & 1.10 & 29.91 & 0.86 & & & \\
\hline \multirow{4}{*}{$\begin{array}{c}\text { Satisfaction on } \\
\text { Customers }\end{array}$} & $\mathrm{SC} 1$ & 1.00 & - & 0.57 & \multirow{4}{*}{0.91} & \multirow{4}{*}{0.67} & \multirow{4}{*}{0.79} \\
\hline & $\mathrm{SC} 2$ & 1.12 & 24.11 & 0.69 & & & \\
\hline & SC 3 & 1.09 & 11.80 & 0.64 & & & \\
\hline & $\mathrm{SC} 4$ & 1.15 & 12.41 & 0.77 & & & \\
\hline $\begin{array}{l}\text { Goodness-of-fit: } \\
\text { IFI }=0.97 ; \quad \text { TLI }=0\end{array}$ & $\begin{array}{l}102.65, p< \\
\mathrm{NFI}=0.95 ;\end{array}$ & $\begin{array}{l}\mathrm{GFI}=0.9 \\
\mathrm{EA}=0.0\end{array}$ & $\mathrm{NFI}=0$. & $\mathrm{CFI}=0$ & 7 ; RFI $=0.94$ & & \\
\hline
\end{tabular}

providing evidence of discriminant validity (Table 6).

\subsection{Structural model and multi-group analysis results}

In order to construct the model, the fitness of each construct was first assessed. Results of the overall model $\left(\chi^{2}=469.71 ; \mathrm{CFI}=0.91\right.$; $\mathrm{RMSEA}=0.06$; NFI $=0.94 ; \mathrm{CFI}=0.96)$ provides a good fit (see Table 7). The results showed that sales' persons' perceived ethical value positively and significantly influences their ethical climate (coefficient $=0.64, \mathrm{p}<0.05)$, supporting hypothesis 1. Also, the role of ethical value on employees' satisfaction with management (coefficient $=0.12, \mathrm{p}<0.05$ ), $\mathrm{co}^{-}$ workers (coefficients $=0.12, p<0.05$ ), supervisor (coefficients $=0.23, \mathrm{p}<0.05)$, and customers (coefficients $=0.17, p<0.05$ ) show that hypotheses 2, 3, 4, and 5 were also supported. Similarly, in this study, the impact of employees' 
〈Table 6〉 Construct means, standard deviations, and correlations.

\begin{tabular}{ccccccc}
\hline & EV & EC & SM & SW & SS & SC \\
\hline EV & 1.00 & & & & & \\
EC & 0.57 & 1.00 & & & & \\
SM & 0.35 & 0.36 & 1.00 & & & \\
SW & 0.32 & 0.32 & 0.40 & 1.00 & & \\
SS & 0.38 & 0.35 & 0.58 & 0.55 & 1.00 & \\
SC & 0.24 & 0.11 & 0.33 & 0.38 & 0.32 & 1.00 \\
Means & 4.92 & 5.28 & 4.57 & 5.38 & 4.92 & 4.90 \\
S.D & 1.87 & 1.61 & 1.40 & 1.17 & 1.61 & 1.28 \\
\hline
\end{tabular}

EV: Ethics Values

EC: Ethics Climate

SM: Satisfaction with Management

SW: Satisfaction with Co-Workers

SS: Satisfaction with Supervisor

SC: Satisfaction with Customers

perceived ethical climate on their satisfaction with management $(\mathrm{H} 6$ : coefficient $=0.20, \mathrm{p}<$ 0.05), co-workers (H7: coefficients $=0.16, p<$ 0.05), supervisor (H8: coefficients $=0.22, p<$ 0.05) was found. However, sales persons' perceived ethical climate did not significantly influence their satisfaction with customers (coefficient $=-0.06, \mathrm{p}>0.05$ ), not supporting H9. Next, multi-group analysis is performed to examine parameter estimate differences between the $\mathrm{B} 2 \mathrm{~B}$ and $\mathrm{B} 2 \mathrm{C}$ groups. Results indicate the difference across groups (see Table 8). For the B2B group, six of the nine paths are significant. For the B2C group, six of the nine paths are significant while the other paths between ethical value with satisfaction with management and co-workers, and ethical climate with satisfaction with customers are not significant. Results of the chi-squared difference test indicate that the relationship between ethical issues and multi-dimensional job satisfaction significantly differ across groups. The parameter estimate for the path between ethical value and ethical climate is stronger $\left(\Delta \chi^{2}=3.234, \mathrm{p}<0.01\right)$ for the B2B $(b=0.89, p<0.01)$ than for the B2C $(b=0.37, p<0.01)$ group. The parameter estimates for the path between ethical value with satisfaction with management, co-workers, and ethical climate with satisfaction with customers are only significant in B2B group. Moreover, the parameter estimates for the path between ethical climate with satisfaction with management, co-workers, and supervisor are only significant in the B2C group. 
〈Table 7〉 Results of structural equation modelling of overall model.

\begin{tabular}{lcc}
\hline \multicolumn{1}{c}{ Structural Path } & Coefficient & t-Value \\
\hline Ethics Values $\rightarrow$ Ethics Climate & 0.464 & $13.645^{* * *}$ \\
Ethics Values $\rightarrow$ Satisfaction with Management & 0.117 & $3.466^{* * *}$ \\
Ethics Values $\rightarrow$ Satisfaction with Co-Workers & 0.124 & $3.652^{* * *}$ \\
Ethics Values $\rightarrow$ Satisfaction with Supervisor & 0.234 & $5.086^{* * *}$ \\
Ethics Values $\rightarrow$ Satisfaction with Customers & 0.172 & $4.575^{* * *}$ \\
Ethics Climate $\rightarrow$ Satisfaction with Management & 0.202 & $4.247^{* * *}$ \\
Ethics Climate $\rightarrow$ Satisfaction with Co-Workers & 0.155 & $3.256^{* *}$ \\
Ethics Climate $\rightarrow$ Satisfaction with Supervisor & 0.215 & $3.389^{* * *}$ \\
Ethics Climate $\rightarrow$ Satisfaction with Customers & -0.055 & -1.145 \\
\hline
\end{tabular}

sGoodness-of-fit： $\chi 2156=469.71, p<0.00 ; \mathrm{GFI}=0.91 ; \mathrm{NFI}=0.94 ; \mathrm{CFI}=0.96 ; \mathrm{IFI}=0.96 ; \mathrm{TLI}=0.95$; RFI $=0.93 ;$ RMSEA $=0.06$

*** $\mathrm{p}<0.001, * * \mathrm{p}<0.01, * \mathrm{p}<0.05$

$\langle$ Table 8> Comparison of the path coefficients between B2B and structural equation models

\begin{tabular}{|c|c|c|c|}
\hline Structural Path & $\begin{array}{c}\text { B2B } \\
\text { Coefficient } \\
\text { (t-Value) }\end{array}$ & $\begin{array}{c}\text { B2C } \\
\text { Coefficient } \\
\text { (t-Value) }\end{array}$ & $\begin{array}{l}\text { Critical } \\
\text { Ration }\end{array}$ \\
\hline Ethics Values $\rightarrow$ Ethics Climate & $\begin{array}{l}0.89 \\
(10.507)^{* * *}\end{array}$ & $\begin{array}{l}0.365 \\
(8.964)^{* * * *}\end{array}$ & $3.234^{* * *}$ \\
\hline Ethics Values $\rightarrow$ Satisfaction on Management & $\begin{array}{l}0.216 \\
(4.139)^{* * * *}\end{array}$ & $\begin{array}{l}0.042 \\
(0.927)\end{array}$ & $2.516^{*}$ \\
\hline Ethics Values $\rightarrow$ Satisfaction with Co-Workers & $\begin{array}{l}0.193 \\
(4.156)^{* * *}\end{array}$ & $\begin{array}{l}0.048 \\
(0.979)\end{array}$ & $2.154^{*}$ \\
\hline Ethics Values $\rightarrow$ Satisfaction with Supervisor & $\begin{array}{l}0.284 \\
(4.137)^{* * * *}\end{array}$ & $\begin{array}{l}0.163 \\
(2.654)^{* *}\end{array}$ & 1.314 \\
\hline Ethics Values $\rightarrow$ Satisfaction with Customers & $\begin{array}{l}0.245 \\
(4.302)^{* * *}\end{array}$ & $\begin{array}{l}0.127 \\
(2.600)^{* *}\end{array}$ & 1.567 \\
\hline Ethics Climate $\rightarrow$ Satisfaction with Management & $\begin{array}{l}0.073 \\
(1.324)\end{array}$ & $\begin{array}{l}0.370 \\
(4.293)^{* * * *}\end{array}$ & $-2.894^{* *}$ \\
\hline Ethics Climate $\rightarrow$ Satisfaction with Co-Workers & $\begin{array}{l}-0.016 \\
(-0.326)\end{array}$ & $\begin{array}{l}0.424 \\
(4.665) * * *\end{array}$ & $-4.238 * * *$ \\
\hline Ethics Climate $\rightarrow$ Satisfaction with Supervisor & $\begin{array}{l}0.080 \\
(1.071)\end{array}$ & $\begin{array}{l}0.455 \\
(4.041)^{* * *}\end{array}$ & $-2.770^{* * *}$ \\
\hline Ethics Climate $\rightarrow$ Satisfaction with Customers & $\begin{array}{l}-0.190 \\
(-3.178) * *\end{array}$ & $\begin{array}{l}0.080 \\
(0.970)\end{array}$ & $-2.650 * *$ \\
\hline
\end{tabular}

Retail Employees' Ethical Value and Climate on Multidimensional Job Satisfaction: A Comparative Study with B2B Employees 81 


\section{Discussions, implications and conclusion}

As issues concerning organizations ethics emerge as a significant agenda in modern society, ethical management also determines corporate continuity. An organization with deep-rooted ethical management can enhance its reliability in relation to investors and customers based on organizational transparency and fair competition. Min et al. (2014) developed a theoretical model of green purchasing capability and explained eco-friendly corporations have a competitive advantage, which can lead to financial achievements. Ethical management includes moral norms and rules concerning organizations and employees, as well as upright values of the management. As such, this research examines ethical issues (i.e., ethical values and ethical climates) as antecedents to the multidimensional job satisfaction of salespersons.

The model was examined contextually across $\mathrm{B} 2 \mathrm{~B}$ and B2C settings. The role of both ethical values and climate in the formation of employees' satisfaction with management, co-workers, and supervisor was found. More importantly, the relative impact of ethical values and climate on multidimensional job satisfaction was supported. Among suppliers, ethical values more positively influence their job satisfaction. In contrast, the impact of ethical climate on employees' satisfaction with management, coworkers, and supervisor was greater among employees in the $\mathrm{B} 2 \mathrm{C}$ setting. It should be noted there are different roles for ethical issues across B2B and B2C employees.

\subsection{Theoretical implications}

This study was conducted to examine and compare the impact of ethical issues (e.g., ethical value and ethical climate) on multidimensions of job satisfaction (e.g., satisfaction with management, supervisor, co-workers, and customers) between B2B and B2C settings. Thus, this study contributes to service and retailing studies in three ways. First, the results of this study indicate the effect of a company's ethical environment on employee job satisfaction differs according to the type of company. Researchers have examined the relationship between ethical issues and job satisfaction in the hotel (Wong and Li 2015) and pharmaceutical industries (Mulki, Jaramillo, and Locander, 2009). Similar to previous studies, our findings show the impact of ethical issues (e.g., ethical value, ethical climate) on job satisfaction among sales persons. Because retaining current employees is getting difficult in the retailing industry, understanding the potential drivers of employees' job satisfaction is critical to obtain desirable and sustainable growth. Thus, this study is able to expand previous retailing and service literature by examining the role of ethical 
environments among sales persons.

Second, the finding provides strong support for the importance of examining the impact of ethical issues using multi-dimensional measures of job satisfaction. As mentioned above, the results show the positive and significant impact of both ethical values and climate on employees' satisfaction with management, co-workers, and supervisors. As Deshpande (1996) suggested, this study also provides a need to understand multi-faceted job satisfaction. Employees who regard perceive ethical value and organization climate tend to remain satisfied with their job, which may increase their performance. However, in this study, the impact of ethical climate on sales persons' satisfaction with customers was not supported. This can be explained with the characteristics of each sample, either B2B or B2C.

Lastly, differences regarding the influence of ethical values and issues on various satisfaction facets across the B2B and B2C groups were found. The finding indicates the ethical value predicts multiple-satisfaction better within the B2B context than the B2C environments. Given this, B2B organization actually provided better ethical values, increasing employee job satisfaction. The comparison of parameter estimates shows that ethical climate has a greater influence on satisfaction with work for B2C than B2B employees. B2C employees generally work more closely so the organization's climate has a bigger impact for $\mathrm{B} 2 \mathrm{C}$ employees than for $\mathrm{B} 2 \mathrm{~B}$ salespeople. Therefore, by creating an ethical climate that promotes ethical conduct, companies positively build ethical behavior in salespeople. This research provides evidence about the relationships and comparative strength of the ethical value and climate across B2B and B2C salespeople.

\subsection{Managerial implications}

The findings discussed above lead to important managerial recommendations. Service companies should be aware of opportunities to increase employees' satisfaction and their performance by building positive organizational ethical environments. Specifically, this study provides the understanding of how organizations' ethical value and climate promote employees' various types of job satisfaction.

Managers can understand the different roles ethical value and climate play in satisfaction of various types of jobs by using the proposed survey items. Some organizational practices may be targeting exclusively to promote a certain type of ethical environment, and other practices may be emphasizing to enhance different types of job satisfaction simultaneously. Based on such a different impact, managers should carefully design human resources managerial practices that effectively promote ethical value and climate. For instance, developing training programs which create positive ethical environments would help managers improve 
the overall organizational culture, such as autonomy regarding job performance, increasing competence when using new technology, and relatedness with other employees and customers.

Also, retailing and service companies, which involve with both $\mathrm{B} 2 \mathrm{~B}$ and $\mathrm{B} 2 \mathrm{C}$ settings, should also be aware of the different roles of ethical values and climate on employees' satisfaction. For instance, frontline employees in retail stores tend to value ethical values more than ethical climate when they evaluate the organization. In contrast, employees in the merchandise division might feel more satisfaction when they perceive a high level of ethical climate rather than ethical value. Thus, companies should understand the different characteristics of the $\mathrm{B} 2 \mathrm{~B}$ and $\mathrm{B} 2 \mathrm{C}$ organization to maximize the impact of ethical issues on employee satisfaction and performance.

\section{Limitations and areas of further research}

Limitations of this research warrant future consideration. First, the findings were based on self-reported data, which is vulnerable to bias and distortion. Future research can consider the proposed model using longitudinal designs that allow for greater inferences regarding causality. Second, data were collected using an online access panel from selected populations.
In expanding the findings of this study, researchers are encouraged to use multiple single-company data. Further, the B2B and B2C employee respondents were only from one country. To increase the generalizability of the findings, future research should conduct crossnational or global company studies.

〈Received May 7. 2021〉

〈Revised June 28. 2021〉

$\langle$ Accepted July 27. 2021〉

\section{References}

Abbott, A. (2003). Cell culture: biology's new dimension, Nature, 424, 870-872.

Ahmad, Z., Ahmad, Z., Ahmed, I., and Nawaz, M. M. (2010). Organizational climate (OC) as employees' satisfier: Empirical evidence from pharmaceutical sector. International Journal of Business and Management, 5(10), 214-222.

Alchian, A. A., and Demsetz, H. (1972). Production, information costs, and economic organization. The American Economic Review, 62(5), 777-795.

Ambrose, M. L., Arnaud, A., \& Schminke, M. (2008). Individual moral development and ethical climate: The influence of person organization fit on job attitudes. Journal of Business Ethics, 77(3), 323-333.

Ambrose, M. L., Rice, D. B., and Mayer, D. M. 
(2019). Justice climate and workgroup outcomes: The role of coworker fair behavior and workgroup structure. Journal of Business Ethics, 1-21.

Anaza, N. A., Rutherford, B., Rollins, M., \& Nickell, D. (2015). Ethical climate and job satisfaction among organizational buyers: an empirical study. Journal of Business \& Industrial Marketing, 30(8), 962-972.

Arnaud, A. (2010). Conceptualizing and measuring ethical work climate: Development and validation of the ethical climate index. Business \& Society, 49(2), 345-358.

Aryati, A. S., Sudiro, A., Hadiwidjaja, D., and Noermijati, N. (2018). The influence of ethical leadership to deviant workplace behavior mediated by ethical climate and organizational commitment. International Journal of Law and Management.

Ashraf, M. A. (2019). The mediating role of work atmosphere in the relationship between supervisor cooperation, career growth and job satisfaction. Journal of Workplace Learning

Babin, B. J., and Boles, J. S. (1996). The effects of perceived co-worker involvement and supervisor support on service provider role stress, performance and job satisfaction. Journal of Retailing, 72(1), 57-75.

Babin, B. J., Boles, J. S., and Robin, D. P. (2000). Representing the perceived ethical work climate among marketing employees. Journal of the Academy of Marketing
Science, 28(3), 345-358.

Baker, T. L., Hunt, T. G., \& Andrews, M. C. (2006). Promoting ethical behavior and organizational citizenship behaviors: The influence of corporate ethical values. Journal of Business Research, 59(7), 849857

Boo, E., \& Koh H.C. (2004). Are client-perceived audit firm reputation and audit team attributes associated with bigN audit fees? Working Paper, Nanyang Technological University, 1-34

Booth, S., and Hamer, K. (2007). Labour turnover in the retail industry. International Journal of Retail \& Distribution Management, 34(4), 289-307.

Brown, S. P., and Lam, S. K. (2008). A meta-analysis of relationships linking employee satisfaction to customer responses. Journal of Retailing, 84(3), 243-255.

Byrne, B. M. (2013). Structural equation modeling with LISREL, PRELIS, and SIMPLIS: Basic concepts, applications, and programming. Psychology Press.

Chiou, J. S., Droge, C., and Hanvanich, S. (2002). Does customer knowledge affect how loyalty is formed? Journal of Service Research, 5(2), 113-12

Chung, T. L., Rutherford, B., and Park, J. (2012). Understanding multifaceted job satisfaction of retail employees. International Journal of Retail \& Distribution Management, 40(9), 699-716. 
Churchill Jr, G. A., Ford, N. M., and Walker Jr, O. C. (1974). Measuring the job satisfaction of industrial salesmen. Journal of Marketing Research, 11(3), 254-260.

Chye Koh, H., and Boo, E. F. H. (2004). Organisational ethics and employee satisfaction and commitment. Management Decision, 42(5), 677-693.

Coelho, F. J., Augusto, M. G., Coelho, A. F., and Sá, P. M. (2010). Climate perceptions and the customer orientation of frontline service employees. The Service Industries Journal, 30(8), 1343-1357.

Comer, J. M., Machleit, K. A., and Lagace, R. R. (1989). Psychometric assessment of a reduced version of INDSALES. Journal of Business Research, 18(4), 291-302.

Cullen, J. B., Parboteeah, K. P., and Victor, B. (2003). The effects of ethical climates on organizational commitment: A two-study analysis. Journal of Business Ethics, 46(2), 127-141.

Deshpandé, R., and Farley, J. U. (2004). Organizational culture, market orientation, innovativeness, and firm performance: an international research odyssey. International Journal of Research in Marketing, 21(1), 3-22.

Deshpande, S. P. (1996). The impact of ethical climate types on facets of job satisfaction: An empirical investigation. Journal of Business Ethics, 15(6), 655-660.

Dixon, A. L., and Tanner Jr, J. J. F. (2012).
Transforming selling: why it is time to think differently about sales research. Journal of Personal Selling \& Sales Management, 32(1), 9-13.

Ekvall, G. (1996). Organizational climate for creativity and innovation. European Journal of Work and Organizational Psychology, 5(1), 105-123.

Fatima, J. K., and Di Mascio, R. (2018). Reversing the dependency-trust relationship in B2C services. Journal of Retailing and Consumer Services, 41, 1-10.

Festinger, L. (1957). A theory of cognitive dissonance (Vol. 2). Stanford university press.

Fornell, C., and Larcker, D. F. (1981). Evaluating structural equation models with unobservable variables and measurement error. Journal of Marketing Research, 18(1), 39-50.

Hair, J. F., Anderson, R. E., Babin, B. J., and Black, W. C. (2010). Multivariate data analysis: A global perspective (Vol. 7) : Pearson Upper Saddle River.

Hartmann, N. N., Rutherford, B. N., and Park, J. (2017). Sequencing of multi-faceted job satisfaction across business-to-business and business-to-consumer salespeople: A multi-group analysis. Journal of Business Research, 70, 153-159.

Heugen, U., Schwaab, G., Bründermann, E., Heyden, M., Yu, X., Leitner, D. M., and Havenith, M. (2006). Solute-induced retardation of water dynamics probed 
directly by terahertz spectroscopy. Proceedings of the National Academy of Sciences, 103(33), 12301-12306.

Hoejmose, S., Brammer, S., and Millington, A. (2012). "Green" supply chain management: The role of trust and top management in B2B and B2C markets. Industrial Marketing Management, 41(4), 609-620.

Huhtala, M., Feldt, T., Hyvönen, K., and Mauno, S. (2013). Ethical organisational culture as a context for managers' personal work goals. Journal of Business Ethics, 114(2), 265-282.

Huhtala, M., Feldt, T., Lämsä, A. M., Mauno, S., and Kinnunen, U. (2011). Does the ethical culture of organisations promote managers' occupational well-being? Investigating indirect links via ethical strain. Journal of Business Ethics, 101(2), 231-247.

Hunt, S. D., Wood, V. R., and Chonko, L. B. (1989). Corporate ethical values and organizational commitment in marketing. Journal of Marketing, 53(3), 79-90.

Hurst, J. L., and Good, L. K. (2009). Generation $\mathrm{Y}$ and career choice: The impact of retail career perceptions, expectations and entitlement perceptions. Career Development International, 14(6), 570-593.

Jafri, M. H., Dem, C., and Choden, S. (2016). Emotional intelligence and employee creativity: Moderating role of proactive personality and organizational climate.
Business Perspectives and Research, 4(1), 54-66.

Jaramillo, F., Mulki, J. P., and Solomon, P. (2006). The role of ethical climate on salesperson's role stress, job attitudes, turnover intention, and job performance. Journal of Personal Selling \& Sales Management, 26(3), 271-282.

Joseph, J., and Deshpande, S. P. (1997). The impact of ethical climate on job satisfaction of nurses. Health Care Management Review, 22(1), 76-81.

Jones, E., Busch, P., and Dacin, P. (2003). Firm market orientation and salesperson customer orientation: interpersonal and intrapersonal influences on customer service and retention in business-to-business buyer-seller relationships. Journal of Business Research, 56(4), 323-340.

Jung, H. S., Namkung, Y., \& Yoon, H. H. (2010). The effects of employees' business ethical value on person-organization fit and turnover intent in the foodservice industry. International Journal of Hospitality Management, 29(3), 538-546.

Kaptein, M. (2011). From inaction to external whistleblowing: The influence of the ethical culture of organizations on employee responses to observed wrongdoing. Journal of Business Ethics, 98(3), 513-530.

Kish-Gephart, J. J., Harrison, D. A., \& Treviño, L. K. (2010). Bad apples, bad cases, and bad barrels: meta-analytic evidence about 
sources of unethical decisions at work. Journal of Applied Asychology, 95(1), 1-31.

Koh, H. C., and El'Fred, H. Y. (2001). The link between organizational ethics and job satisfaction: A study of managers in Singapore. Journal of Business Ethics, 29 (4), 309-324.

Kwon, U., Beatty, S. E., \& Lueg, J. E. (2000). Organizational values, work norms, and relational role behaviours: An empirical retail assessment. The International Review of Retail, Distribution and Consumer Research, 10(4), 401-416.

Lau, P. Y. Y., Tong, J. L. T., Lien, B. Y. H., Hsu, Y. C., and Chong, C. L. (2017). Ethical work climate, employee commitment and proactive customer service performance: Test of the mediating effects of organizational politics. Journal of Retailing and Consumer Services, 35, 20-26.

Lee, K. S., \& Gao, T. (2005). Studying organizational commitment with the OCQ in the Korean retail context: Its dimensionality and relationships with satisfaction and work outcomes. The International Review of Retail, Distribution and Consumer Research, 15(4), 375-399.

Lin, W. L., Yip, N., Ho, J. A., \& Sambasivan, M. (2020). The adoption of technological innovations in a B2B context and its impact on firm performance: An ethical leadership perspective. Industrial Marketing
Management, 89, 61-71.

Luthans, F., Norman, S. M., Avolio, B. J., and Avey, J. B. (2008). The mediating role of psychological capital in the supportive organizational climate-employee performance relationship. Journal of Organizational Behavior: The International Journal of Industrial, Occupational and Organizational Psychology and Behavior, 29(2), 219-238. Malik, M. E., Ali, R., Ghafoor, M. M., and Danish, R. Q. (2011). Perception of Job Psychology: Moderating Role of Age on Relationship Between Job Climate, Extrinsic Rewards and Job Satisfaction. World Applied Sciences Journal, 13(6), 1367-1374.

Martin, K. D., and Cullen, J. B. (2006). Continuities and extensions of ethical climate theory: A meta-analytic review. Journal of Business Ethics, 69(2), 175-194. Mayer, D. M., Kuenzi, M., Greenbaum, R., Bardes, M., \& Salvador, R. B. (2009). How low does ethical leadership flow? Test of a trickle-down model. Organizational Behavior and Human Decision Processes, 108(1), $1-13$.

Mencarelli, R., and Riviere, A. (2014). La participation du client dans un contexte de self-service technologies. Revue Française De gestion, 4, 13-30.

Min, S. H., Im, S. B., \& Kogan, T. T. (2014). Mediating Effects of Green Purchasing Capability on the Organizational Characteristics -Firm Performance Relationship. Asia 
Marketing Journal, 16(1), 13-20.

Mulki, J. P., Jaramillo, J. F., and Locander, W. B. (2009). Critical role of leadership on ethical climate and salesperson behaviors. Journal of Business Ethics, 86(2), 125-141. Mujtaba, B. G., \& Sims, R. L. (2006). Socializing retail employees in ethical values: The effectiveness of the formal versus informal methods. Journal of Business and Psychology, 21(2), 261-272.

Pagliaro, S., Lo Presti, A., Barattucci, M., Giannella, V. A., and Barreto, M. (2018). On the effects of ethical climate (s) on employees' behavior: a social identity approach. Frontiers in Psychology, 9, 960

Parsons, E., and Broadbridge, A. (2006). Job motivation and satisfaction: Unpacking the key factors for charity shop managers. Journal of Retailing and Consumer Services, 13(2), 121-131.

Park, J. C., Kim, K. J., \& Lee H. J. (2010). Developing a Scale for Measuring the Corporate Social Responsibility Activities of Korea Corporation: Focusing on the Consumers' Awareness. Asia Marketing Journal, 12(2), 27-52.

Park, J., Yoo, W. S., \& Rutherford, B. (2015). Sales people as emotional laborers: psychological and behavioral outcomes. Asia Marketing Journal, 16(4), 39-57.

Patterson, M., Warr, P., and West, M. (2004). Organizational climate and company productivity: The role of employee affect and employee level. Journal of Occupational and Organizational Psychology, 77(2), 193-216.

Pettijohn, C., Pettijohn, L., and Taylor, A. J. (2008). Salesperson perceptions of ethical behaviors: Their influence on job satisfaction and turnover intentions. Journal of Business Ethics, 78(4), 547-557.

Plouffe, C. R., Sridharan, S., and Barclay, D. W. (2010). Exploratory navigation and salesperson performance: Investigating selected antecedents and boundary conditions in high-technology and financial services contexts. Industrial Marketing Management, 39(4), 538-550.

Prottas, D. J. (2013). Relationships among employee perception of their manager's behavioral integrity, moral distress, and employee attitudes and well-being. Journal of Business Ethics, 113(1), 51-60.

Riggle, R. J., Edmondson, D. R., and Hansen, J. D. (2009). A meta-analysis of the relationship between perceived organizational support and job outcomes: 20 years of research. Journal of Business Research, 62(10), 1027-1030.

Rutherford, B. N., Boles, J. S., and Ambrose, S. C. (2019). Reconceptualizing the measurement of multidimensional salesperson job satisfaction. Journal of Personal Selling \& Sales Management, 39(3), 287-298.

Schwepker, C. H., Ferrell, O. C., and Ingram, T. N. (1997). The influence of ethical 
climate and ethical conflict on role stress in the sales force. Journal of the Academy of Marketing Science, 25(2), 99-108.

Schwepker Jr, C. H. (1999). Research note: The relationship between ethical conflict, organizational commitment and turnover intentions in the salesforce. Journal of Personal Selling \& Sales Management, 19 (1), 43-49.

Schwepker Jr, C. H. (2001). Ethical climate's relationship to job satisfaction, organizational commitment, and turnover intention in the salesforce. Journal of Business Research, 54(1), 39-52.

Schwepker Jr, C. H., and Good, D. J. (2004). Marketing control and sales force customer orientation. Journal of Personal Selling \& Sales Management, 24(3), 167-179.

Schwepker Jr, C. H., and Hartline, M. D. (2005). Managing the ethical climate of customercontact service employees. Journal of Service Research, 7(4), 377-397.

Schwepker, C. H. (2019). Strengthening Customer Value Development and Ethical Intent in the Salesforce: The Influence of Ethical Values Person - Organization Fit and Trust in Manager. Journal of Business Ethics, 159(3), 913-925

Sims, R. L., and Keon, T. L. (1997). Ethical work climate as a factor in the development of person-organization fit. Journal of Business Ethics, 16(11), 1095-1105.

Sims, R. L., and Kroeck, K. G. (1994). The influence of ethical fit on employee satisfaction, commitment and turnover. Journal of Business Ethics, 13(12), 939947.

Swani, K., Brown, B. P., and Milne, G. R. (2014). Should tweets differ for B2B and B2C? An analysis of Fortune 500 companies' Twitter communications. Industrial Marketing Management, 43(5), 873-881.

Teng, C. C., and Barrows, C. W. (2009). Service orientation: antecedents, outcomes, and implications for hospitality research and practice. The Service Industries Journal, 29(10), 1413-1435.

Thurstone, L. L. (1931). Multiple factor analysis. Psychological Review, 38(5), 406.

Treviño, L. K., and Weaver, G. R. (2003). Managing ethics in business organizations: Social scientific perspective. Stanford, CA: Stanford University Press.

Valentine, S., and Barnett, T. (2003). Ethics code awareness, perceived ethical values, and organizational commitment. Journal of Personal Selling \& Sales Management, 23 (4), 359-367.

Verplanken, B. (2004). Value congruence and job satisfaction among nurses: a human relations perspective. International Journal of Nursing Studies, 41(6), 599-605.

Victor, B., and Cullen, J. B. (1987). A theory and measure of ethical climate in organizations. Research in Corporate Social Performance and Policy, 9(1), 51-71. 
Viswesvaran, C., Deshpande, S. P., and Joseph, J. (1998). Job satisfaction as a function of top management support for ethical behavior: A study of Indian managers. Journal of Business Ethics, 17(4), 365-371.

Vitell, S. J., and Davis, D. L. (1990). The relationship between ethics and job satisfaction: An empirical investigation. Journal of Business Ethics, 9(6), 489-494.

Wang, M. L. (2012). How does the learning climate affect customer satisfaction? The Service Industries Journal, 32(8), 12831303.

Wang, Y. D., and Hsieh, H. H. (2012). Toward a better understanding of the link between ethical climate and job satisfaction: A multilevel analysis. Journal of Business Ethics, 105(4), 535-545.

Weeks, W. A., and Nantel, J. (1992). Corporate codes of ethics and sales force behavior: A case study. Journal of Business Ethics, 11(10), 753-760.

Westerman, J. W., and Simmons, B. L. (2007). The effects of work environment on the personality-performance relationship: An exploratory study. Journal of Managerial Issues, 288-305.

Wong, S. C. K., and Li, J. S. (2015). Will hotel employees' perception of unethical managerial behavior affect their job satisfaction? A study of Chinese hotel employees in China. International Journal of Contemporary
Hospitality Management, 27(5), 853-877. Whysall, P., Foster, C., \& Harris, L. (2009). Job dissatisfaction among retail employees: a study of three leading UK retailers. The International Review of Retail, Distribution and Consumer Research, 19(2), 179-198.

Yến, H. H. (2019). Perception on ethical climate and individual job performance of bank employees. Journal of Economic Development, 24(4), 85-98.

Yeşiltaş, M., and Tuna, M. (2018). The effect of ethical leadership on service sabotage. The Service Industries Journal, 38(15-16), 1133-1159.

Yousef, D. A. (2001). Islamic work ethic - A moderator between organizational commitment and job satisfaction in a cross-cultural context. Personnel Review, 30(2), 152-169. Yu, M. C., Mai, Q., Tsai, S. B., and Dai, Y. (2018). An empirical study on the organizational trust, employee-organization relationship and innovative behavior from the integrated perspective of social exchange and organizational sustainability. Sustainability, 10(3), 864-897.

Zhang, R. Y., Liu, X. M., Wang, H. Z., and Shen, L. (2011). Service climate and employee service performance: exploring the moderating role of job stress and organizational identification. The Service Industries Journal, 31(14), 2355-2372. 